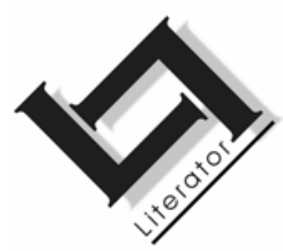

\title{
"Ek is besig om iemand heeltemal anders te word ...": die ontginning van liminaliteit in Vaselinetjie deur Anoeschka von Meck
}

\author{
Dorothea van Zyl \\ Departement Afrikaans en Nederlands \\ Universiteit van Stellenbosch \\ STELLENBOSCH \\ E-pos:dpvz@sun.ac.za
}

\begin{abstract}
"I am becoming someone completely different ...": the utilisation of liminality in Vaselinetjie (Little Vaseline) by Anoeschka von Meck
\end{abstract}

The concepts of liminality, transition and borders are utilised extensively in "Vaselinetjie" by Anoeschka von Meck (2004). This is especially the case regarding her use of characterisation, focalisation, time and space (including place and landscape) in the construction of identity. As a liminal character, Vaseline finds herself in different kinds of liminal spaces on a regular basis, like the children's home, which is foregrounded in the novel, as well as in consecutive preliminal, liminal and postliminal phases. The children's home is an essentially liminal space, but from the perspective of Vaseline it is firstly gradually transformed into a place to which meaning is attached, and secondly to a landscape of belonging, as she expresses her solidarity with the scorned group of children in the home. On the one hand the children's home is characterised by a certain liminal essence, but on the other hand it can be regarded as "a realm of pure possibility" (Turner, 1967:97).

\section{Opsomming}

"Ek is besig om iemand heeltemal anders te word ...": die ontginning van liminaliteit in Vaselinetjie deur Anoeschka von Meck

Die konsepte liminaliteit, oorgange en grense word op talle maniere ontgin in "Vaselinetjie" deur Anoeschka von Meck (2004). Die ontginning geld veral die hantering van karakterisering, 
fokalisasie, tyd en ruimte (wat plek en landskap insluit) in die konstruksie van identiteit. As liminale karakter bevind Vaselinetjie haar voortdurend in verskillende liminale ruimtes, soos die kinderhuis wat voorop gestel word, asook in opeenvolgende preliminale, liminale en postliminale fases. Die kinderhuis is as sodanig 'n essensieel liminale ruimte, maar binne die optiek van Vaselinetjie groei dit eerstens uit tot 'n plek waaraan sy betekenis verbind en tweedens tot 'n landskap van behoort, as sy solidariteit betoon met die veragte kinderhuisgroep. Terwyl die kinderhuis dus enersyds 'n liminale essensie besit, kan dit andersyds beskou word as "a realm of pure possibility" (Turner, 1967:97).

\section{Inleidend}

Vaselinetjie (Von Meck, 2004) het heelwat aandag ontvang van pryskomitees. Dit is bekroon met Via Afrika se MER-prys vir jeuglektuur, die Jan Rabie/Rapport-prys vir vernuwende Afrikaanse prosa én die M-Net-prys vir werke van korter formaat in Afrikaans (Anon., 2005:10). Dat die een prys spesifiek met jeuglektuur verbind kan word, maar die ander twee glad nie, illustreer die mate waarin hierdie roman oor verskillende grense heen gewaardeer word.

Vaselinetjie kan in talle opsigte 'n jeugroman genoem word, maar die manier waarop die gegewens hanteer word, hef ouderdomsgrense grotendeels op. Dit herinner aan 'n ander teks wat ook in 2004 verskyn het, naamlik Roepman deur Jan van Tonder. Albei pas in hierdie opsig binne 'n "tradisie" van Afrikaanse tekste, soos Jeanne Goosen se Ons is nie almal so nie en onder andere. Daantjie Dromer, Mark Behr se Die reuk van appels en S.P. Benjamin se Die reuk van steenkool (vgl. ook Viljoen, 2005). Sowel Vaselinetjie as Roepman beskryf 'n kind (as hoofkarakter) se verlies aan onskuld in interaksie met ander karakters en ruimtes. Daarby werp sekere beslissende gebeurtenisse 'n ander lig op sake. Sodanige aspekte lei tot karakterontwikkeling - tot 'n meer volwasse identiteit, omdat albei hoofkarakters, volgens Viljoen (2005) oor Timus in Roepman, "tydens die oorgangsrites losgemaak word van hulle bekende omstandighede en daarna in ' $n$ ambivalente en tussen-in-toestand verkeer voordat hulle uiteindelik weer opgeneem word in die gemeenskap". In Vaselinetjie word liminaliteit egter op 'n meer omvattende wyse ontgin as in Roepman, veral omdat die gebeure hoofsaaklik binne die liminale ruimte van die kinderhuis afspeel.

Eerstens word 'n kort uiteensetting gegee van enkele relevante teoretiese aspekte wat met liminaliteit en oorgang saamhang. Daarna word veral aandag bestee aan elemente wat te doen het 
met ruimte, plek en landskap, asook met perspektief, om die konstruksie van identiteit in die roman Vaselinetjie te ondersoek.

\section{Liminaliteit}

Romans oor adolessensie, soos Vaselinetjie en Roepman, tematiseer dikwels aspekte wat met oorgang te doen het en gee aandag aan liminale of drumpel-ervarings. Die navorsing oor liminaliteit wat in die twintigste eeu deur antropoloë soos Arnold van Gennep en Victor Turner onderneem is, is dus in die besonder relevant by ' $n$ analise van hierdie tipe romans. Die drie fases wat Arnold van Gennep in 1909 oorspronklik vanuit 'n sosiaalantropologiese konteks met die sogenaamde "rites of passage" verbind het (Van Gennep, 1977:11), naamlik skeidingsrites ("rites of separation, preliminal rites"), liminale rites ("transition rites, liminal rites") en insluitingsrites ("rites of incorporation, postliminal rites"), word byvoorbeeld meermale aangetref in hierdie tipe tekste. Victor Turner (1967:95) se ondersoek na inisiasierites wat die oorgang van jeug na sosiale volwassenheid markeer "... since they have wellmarked and protracted marginal or liminal phases", lewer eweneens nuttige insigte op. My literêre ondersoek na liminaliteit in Vaselinetjie fokus, in aansluiting by hierdie teoretisering, op die wyse waarop aspekte soos karakterisering (karakterontwikkeling en/of -verandering), fokalisasie, tyd en veral ruimte in dié roman aangewend word vir die konstruksie van identiteit.

Victor Turner se referaat uit 1964: "Betwixt and between: the liminal period in Rites de Passage" (Turner, 1967:93-111) verruim Van Gennep se toepassing van die begrip liminaliteit in sy verwysing na drumpelmense wat hulle op 'n grens bevind, in "a realm (...) betwixt and between (...) any type of stable or recurrent condition that is culturally recognised". Hierdie tussenstadium kan onder meer neerslag vind in wette, gebruike, konvensies en seremonies (Turner, 1967:93-94). Omdat die liminale 'n tussenstadium is, word dit dikwels gedefinieer in terme van wat dit nie is nie. Hierdie fase word gekenmerk deur dubbelsinnighede en verwarring, maar dit het nie noodwendig negatiewe gevolge nie: Dit "may perhaps be regarded as the Nay to all positive structural assertions, but as in some sense the source of them all, and, more than that, as a realm of pure possibility whence novel configurations of ideas and relations may arise" (Turner, 1967:97). Soos uit die bespreking sal blyk, gee die liminale fase van Vaselinetjie se verblyf in die kinderhuis inderdaad aanleiding tot nuwe moontlikhede; tot nuwe konfigurasies van idees en verhoudings. 
Van Gennep en Turner se idees en konsepte het sedertdien ruim neerslag gevind in navorsing gemoeid met verskillende velde. Die verbinding tussen die liminale en spesifiek die ruimtelike word byvoorbeeld gelê in artikels so uiteenlopend soos dié deur Endsjø (2000) en Bain (2003). Uit 'n klassiek-kulturele hoek ontleed Endsjø liminale ruimtes in die antieke Griekse perspektief op die wêreld. Hierin steun hy sterker op die betekenis wat Van Gennep oorspronklik aan oorgangsrites geheg het. Bain (2003) se artikel handel oor "urban space", soos uitgebeeld in resente tienerfilms uit Hollywood. Albei artikels lewer nuttige insigte vir die verstaan van Vaselinetjie.

Endsjø se artikel handel veral oor die ongekultiveerde ruimtes buite die stadsmure waarheen jong Griekse mans as onderdeel van inisiasierites ontvoer is, sodat hulle volwassenheid en 'n reg op burgerskap kon verwerf (2000:358). Hierdie ruimtes word gestel teenoor die sentrale stadsruimte of polis. Hoewel die kinderkarakters in Vaselinetjie op 'n veel laer sosiaal-maatskaplike vlak funksioneer en daar nie soveel sprake is van genderskeiding nie (buiten vir die verskillende geboue waarin die seuns en die dogters gehuisves word), kan Endsjø se teoretisering oor die konstruksie van plekke met "a certain liminal essence" (Endsjø, 2000:357) goed in verband gebring word met die kinderhuis as liminale ruimte in Vaselinetjie.

Endsjø (2000:356) wys daarop dat Van Gennep reeds die weg geopen het vir die idee dat sekere grensareas 'n verstandelike en sosiale oorgang verteenwoordig vir diegene wat dit oorskry. Ook Turner was volgens hom, met betrekking tot die liminale fase, bewus van die belangrike rol wat ruimte binne 'n gegewe kulturele konteks kan speel, veral ten opsigte van sy idee van 'n "realm (...) betwixt and between" (Turner, 1967:93). Endsjø beskou liminale ruimtes as "spatial 'remains'" wat ook kulturele konstruksies verteenwoordig. Hy lig die belang van perspektief uit, deur ruimte en plek te verbind met 'n "autonomous liminal status within a given worldview". Hy beweer:

As culturally recognised places are carved out of an originally undefined territory, huge areas will also remain outside of these culturally recognised frames (...) the periphery seems to possess something of the same phenomenological essence as the liminal phase of the transitional rites, a certain liminal essence that belongs to these landscapes, quite independent of transitional rites" (Endsjø, 2000:357).

Endsjø verkies Van Gennep se oorspronklike visie van "the undefined, transitional areas as loaded with meaning projected onto it by the culture that contemplated it" (Endsjø, 2000:357), waarby 
perspektief nogmaals voorop gestel word, bo Turner se visie van "the culturally undefined space as a neutral ground that could only acquire a quality of liminality through some liminal ritual taking place there" (Turner, 2000:357). Endsjø se visie kan van toepassing gemaak word op die konstruksie van die kinderhuismilieu in Vaselinetjie, waarby verskillende perspektiewe 'n vername rol speel. Belangrik hierby is, myns insiens, die verskil tussen die uitbeelding van die kinderhuis as ruimte met 'n sekere liminale essensie en Vaselinetjie se eie veranderende perspektief daarop tydens 'n uitgebreide tydperk van oorgang. Dit behels dat die kinderhuis steeds 'n sekere liminale essensie behou, maar dat die persone wat dit bewoon deur verskillende en wisselende fases van liminaliteit gaan.

Endsjø se formulering roep vir my 'n verband op met die onderskeid wat Darian-Smith et al. (1996:3) tref tussen die begrippe ruimte, plek en landskap: "It is through the cultural process of imagining, seeing, historicizing and remembering that space is transformed into place, and geographical territory into a culturally defined landscape." Dit behels dat plek op ruimte dui waaraan betekenis verleen word met behulp van onder andere fokalisasie, terwyl landskap spesifiek met kultuur verbind word. In Vaselinetjie kan myns insiens 'n progressie in die hoofkarakter se siening van die kinderhuis aangedui word, soos uitgewys sal word in die roman-analise: wat aanvanklik 'n liminale ruimte was, word geleidelik vir haar 'n plek waaraan betekenis verbind word en groei op die lange duur binne haar optiek uit tot 'n kultureel-gedefinieerde landskap van behoort. In dié proses kry die hoofkarakter te make met skeidingsrites, liminale rites en uiteindelik insluitingsrites in die preliminale, liminale en postliminale fases waardeur sy as karakter ontwikkel (Van Gennep, 1977:11).

Bain (2003:197) se artikel gaan op 'n heeltemal ander manier met veral Turner se konsepte om. Bain ondersoek filmiese konstruksies van die wêreld van hoofsaaklik wit Amerikaanse adolessente meisies (wat sy screenagers noem) in nege Hollywood tienerfilms, as fiksionele tekste wat op vermaak ingestel is. Haar bevindings kontrasteer sterk met die wyse waarop perspektiewe op die "ander" in Vaselinetjie aan die bod kom. Bain vind dat die meeste van die geselekteerde films "a very 'white' notion of adolescence" konstrueer, anders as wat akademiese studies te kenne gee:

If non-white girls are cast, they are only peripheral figures, relegated to minor roles that conform to racist stereotypes. In mainstream Hollywood teen films, whiteness is a non-issue; questions of white privilege and power are largely unaddressed. 
Die teendeel hiervan word aangetref in die roman Vaselinetjie, waar die kleurkwessie juis 'n sentrale plek inneem. Dit dien byvoorbeeld as die motoriese moment van en motivering vir Vaselinetjie se vertrek na die kinderhuis.

Van belang vir dié bespreking is egter wel die volgende onderskeid wat Bain maak: Dit gaan volgens haar (Bain, 2003:201) by die tieners wat uitgebeeld word nie soseer om 'n binêre opposisie tussen "public space" en "private space" nie, maar eerder om "space to be with people or space to be alone". Die huis, waar 'n mens dopgehou word deur jou gesin, is dus vir sommige tienermeisies ' $n$ openbare ruimte, en hulle private ruimte is eerder die groter anonimiteit van ruimtes buite die huis. Naas "retreat space" en "interaction space" (Bain, 2003:197, 202) onderskei sy ook nog "liminal space" binne die "limited palette of spaces" wat hierdie tienermeisies approprieer. Studies deur onder andere Sebba en Churchman (1983), Larson (1995) en Steele en Brown (1995) wys volgens Bain (2003:201) daarop dat Westerse tienermeisies gewoonlik hulle slaapkamer (as terugtrekruimte) as die intiemste persoonlike ruimte beskou, aangesien dit voel asof dit aan hulle behoort en hulle ook verteenwoordig. Daarnaas sosialiseer tieners gewoonlik op bepaalde plekke in die samelewing (interaksieruimte) waar hulle tuis voel, hetsy in vriende se huise, klubs, kafees, ensovoorts. Bain verbind liminale ruimte, in navolging van Sibley (1995:33), met "spaces of ambiguity and discontinuity". Hier gaan dit om:

... the transformative potential of space. Transformation through use challenges and redefines the potential of space, liberating it from easy categorisation, and empowering young women to challenge and negotiate an adult world of rules and regulations" (Bain, 2003:202-203).

Die wagwoorde hier is "freedom, flexibility and transformation". Sulke tipe ruimtes (bv. motors, parkeerplekke, ensovoorts) hou vir Bain (2003:204) verband met Turner se suggestie van "permanent 'liminoid' settings and spaces (...) bars, pubs, some cafe's, and social clubs" (Turner, 1982:55). Hoewel daar sekerlik met betrekking tot die kinderhuis min sprake is van vryheid vir Vaselinetjie, veral aanvanklik, en nog minder van die genoemde tipe ruimtes, is Bain se onderskeidings wel relevant by 'n studie van hierdie roman, soos dit uitgewys word in die analise. Vaselinetjie se kamer tuis word as terugtrekruimte vervang met haar bed in die kinderhuis; die kinderhuis self kan (nogmaals) as 'n essensieel liminale ruimte 
beskou word, wat egter geleidelik vanuit Vaselinetjie se optiek uitgroei tot 'n ruimte van interaksie.

By die karakterisering in Vaselinetjie gaan dit laastens ook om die konstruksie van 'n identiteit wat allermins staties is, maar wat juis gedurende die puberteit en adolessensie voortdurend ontwikkel en verander. Identiteit beskou ek, soos Lenelle Foster (2004:77) as 'n "veelvlakkige konstruksie (...) wat deur 'n verskeidenheid faktore bepaal word". Wekker en Lutz (2001:39) onderskei byvoorbeeld, op grond van Williams (1998), vyf asse van "maatschappelijke betekenisgeving", naamlik geslag, etnisiteit, klas, nasionaliteit en seksualiteit, wat as merkers van identiteit kan dien. Foster (2004:77) verbind hierdie asse onder andere met die "grense wat liminale karakters oorskry". Dit kan ook by uitstek van toepassing gemaak word op Vaselinetjie.

In die hieropvolgende bespreking word die onderskeie teoretiese uitgangspunte aan die roman Vaselinetjie getoets.

\section{Die liminale, drumpels en grense in Vaselinetjie}

Naas die feit dat Vaselinetjie (soos genoem) as teks op die grens tussen 'n jeug- en 'n boek vir volwassenes lê, word op allerlei maniere met die liminale gespeel. Selfs met betrekking tot omvang lê die boek blykbaar op 'n grens: Olivier (2005) noem dit in 'n uiters negatiewe resensie oor die roman, 'n novelle, maar myns insiens het die teks eerder die omvang van 'n roman.

Vaselinetjie kan eerstens 'n liminale karakter genoem word wat grense oorskry (Foster 2004:77). Die beskrywing van haar geboorte toon reeds dat haar identiteit nie vas staan met betrekking tot "asse" van maatskaplike betekenistoekenning soos etnisiteit, klas en nasionaliteit nie (vgl. Wekker \& Lutz, 2001:39). Dit bly deurgaans onbekend wie haar ma en pa is en gevolglik wat haar etniese afkoms, klas en nasionaliteit is. Die roman open met die fokalisasie van 'n naamlose jong meisie wat klaar is met haar "huiswerk" (dit is ook onseker of sy 'n skolier is of 'n huishulp). Sy maak haar gereed vir die geboorte van haar baba, sonder dat enigeen omgee, sy begewe haar vervolgens na 'n liminale ruimte buite die dorp, agter die begraafplaas naby die lokasie en 'n klipkoppie; sy skenk in eensaamheid en pyn geboorte, laat die baba agter om te sterf en 
gaan self dood of verdwyn (Von Meck, 2004:5-6) ${ }^{\mathbf{1}}$. Dit is hier reeds opvallend in watter mate ruimtelike elemente voorop gestel word:

As sy net agter die eerste koppie kon kom!

Eers het sy net gestap - tot buite die dorp, tot agter die begraafplaas se laaste muurtjie. Niemand kom ooit daar nie. Sy het presies geweet waarheen om te gaan, want sy het maande gelede al na al die plekke gaan kyk. Soos 'n kat voor die tyd 'n veilige hoekie in 'n krat vir haar werpsel gaan soek (p. 6).

Hierdie saaklike soort beskrywing wat die nadruk op ruimtelike aspekte eerder as op patos laat val, is deurgaans in die roman 'n effektiewe skrywerstrategie om sentimentaliteit teen te werk. Dit dui terselfdertyd aan hoe nóú die karakterisering, fokalisasie, ruimtebeelding en die konstruksie van identiteit in hierdie roman met mekaar verweef is.

Die bloed aan die jong vrou se bene verskaf 'n skakel na 'n dogtertjie van ongeveer elf jaar wat ook bloed aan haar bene het, maar dan omdat sy deur haar bruin medeskoliere geviktimiseer word weens haar lang swart hare en ligte gelaatskleur. Die andersoortige bloedverwantskap is 'n skakel wat laat vermoed dat Vaselinetjie die baba was van wie in die vorige gedeelte sprake was.

Die vertelsituasie verander, deurdat daar steeds sprake is van ' $n$ eksterne fokalisator, maar die leser kry in die res van die roman hoofsaaklik Vaselinetjie se perspektief op sake. (Enkele kere skemer die vertelinstansie se stem wel deur, soos op p. 41, waar die perspektief versteur word.) Van die geleidelik bykans volwasse geworde Vaseline se fokalisasie word slegs weer afgestap teen die einde, wanneer Vaseline se oupa, in verklaringstyl, verslag doen van hoe hy die verwaarlooste baba gevind het. Omdat die polisie nie belang gestel het in haar toe hulle vermoed het sy is bruin nie, besluit hy om haar huis toe te neem: "Die polieste ja my toe weg. Sê ek moenie hulle tyd kom stat en mors met nog 'n hotnosbaby wat niemand wil hê nie. Hulle wou nie eens vorms invul nie" (p. 244).

Hierdie aanhaling bevestig Vaselinetjie se aanvanklike "status" as naamlose, nasionaliteitslose en identiteitslose persoon. Die feit dat sy Stukkie Vaseline genoem word eerder as Helena Bosman, soos haar pleegouers haar aanvanklik doop, benadruk haar liminaliteit. Sy kry haar naam van die vaseline waarmee hulle haar moet

1 Waar voortaan slegs bladsynommers in die teksverwysings gebruik word, word verwys na Von Meck (2004). 
insmeer na die skade wat haar vel opgedoen het toe sy na haar geboorte weggegooi is. Die insmering word byna 'n ritueel van salwing om te vergoed vir die kwaad wat haar aanvanklik aangedoen is. Dit word ten slotte bevestig as haar oupa sê: "Jy is ons veldbosengeltje, ons weglêkindjie. Ons alles. Salf vir ou mense se harte" (p. 245).

Gelukkig het Vaselinetjie dus wel ook 'n ouma en oupa wat haar op die hande dra. Vaselinetjie se slaapkamer en bed word, in aansluiting by Bain (2003:201) se onderskeidings, vir haar 'n "retreat space"; 'n geborge ruimte waarna sy steeds terughunker (p. 21, 35, 47 ), soos haar ma se kamer aanvanklik vir háár 'n plek was waar sy haar goed kon wegsteek in haar kas (p. 5) en waar sy haar kon terugtrek - tot die geboorte van Vaselinetjie haar daaruit gedwing het.

Omdat sy te wit voorkom, word Vaselinetjie egter as laerskooldogtertjie uit haar bruin pleegouers se sorg verwyder. Die breër sosio-politieke faktore wat ingryp op Vaselinetjie se bestaan, herinner ironies genoeg eerder aan die apartheidstyd as wat dit getuig van die sogenaamde nuwe Suid-Afrika waarin die roman afspeel. Hierdie ironiese situasie word meermale uitgewys in die roman, onder meer as gesê word dat die kinderhuiskinders "aan Madiba behoort en in sy weeshuis moet bly" (p. 38) en hulle dan te midde van die aaklige toestande sing: "Ons het genoeg gehad van Madiba se pap-en-brood ..." (p. 42).

Vaselinetjie moet afskeid neem van die stabiele omgewing van Keimoes met sy gebruike en konvensies, soos goeie maniere, bedagsaamheid, die ritueel gekoppel aan "daai liefiereuk van Stasoft" as ouma Kitta altyd 'n ekstra lepeltjie by haar wasgoed gooi, sy kerklike en ander seremonies. Die rites, gebruike, konvensies en seremonies wat ingevolge Turner (1967:93-94) verbind kan word met die volgende liminale fase in haar lewe, verskil ingrypend hiervan. Hoewel die eerste gedeelte van Vaselinetjie se lewe, agterna gesien, ook 'n oorgangsfase van baba na kinderhuiskind is, ontbreek die liminale essensie waarna Endsjø (2000:357) verwys in hierdie gestruktureerde en kultureel-bepaalde ruimte.

As skeidings- of preliminale rite (Van Gennep, 1977:11) neem Vaselinetjie se ouers haar ter vertroosting "om iets soets by die keffie in die bodorp te gaan eet" wanneer hulle verneem hulle moet haar na die kinderhuis stuur (p. 12). Opvallend is dat sy, soos haar eie ma, steeds die veld opsoek as die wêreld vir haar te nou word as 't ware 'n persoonlike klein rite: "Sy vlie op en hardloop by die 
agterdeur uit, spring oor die heining by die plek wat al laag gedruk is van al die jare se oorklouter en hol die veld in" (p. 12). Vir haar is die veld egter nie soseer 'n liminale ruimte soos vir haar ma nie, maar eerder 'n vertroude en geliefde plek. Ten slotte sê sy: “Ai, ek't al vergeet hoe lekker die veld ruik ..." (p. 245).

Die eerste liminale ruimte waar Vaselinetjie ingedwing word ná haar afskeid van Keimoes, is die trein waarin sy saam met haar oupa reis en die motor waarin die "Welsynvrou" haar neem tot by Vaselinetjie se nuwe "tuiste" - 'n aaklige, verwaarlooste en onpersoonlike kinderhuis iewers in Gauteng. Sy probeer in hierdie oorgangsituasie onderweg "al die name te onthou soos wanneer sy hard vir 'n eksamen leer. Dis vir die dag wanneer sy die pad terug huis toe gaan vat" (p. 19). Dié liminaliteit blyk ook uit haar eerste negatiewe indrukke van die nuwe milieu waarheen sy verplaas word: "In die skemerlig kan Vaselinetjie geboue met 'n paar stukkende vensters en 'n verdorde tennisbaan uitmaak, 'n tennisbaan waar onkruid deur die barste groei ..." (p. 19). Die strate van die dorp lyk vir haar moeg, die teerpad smal, die hek "hang nog net aan 'n skarnier" (p. 20) en niemand "kom buitentoe om hulle te verwelkom nie ...". Die kinderhuis, wat as ruimte verreweg die meeste aandag in die roman ontvang, is hiervolgens duidelik 'n ruimte met 'n sekere liminale essensie (Endsjø, 2000:357), maar is daarnaas ook 'n area wat duidelik apart geplaas is (Turner \& Turner, 1978:4).

Die ruimte het 'n groot impak op Vaselinetjie se perspektief op haarself en lei tot 'n identiteitskrisis, in Ashcroft (1989:9) se terme: "A valid and active sense of self may have been eroded by dislocation ...". Op p. 35 word dit soos volg opgesom: "Vaselinetjie kan maar net nie gewoond raak aan die vreemde kinderhuislewe met sy loeiende sirenes, bakleiende kinders en nors tannies nie." Die slaapsaal met sy opmekaar beddens, bedkassies en kaste sonder kasdeure kontrasteer sterk met haar "eie groot sagte bed met die vrolike bedspread" (p. 21), maar haar bed raak (soos die leë swembad, wat haar geheime plek is) nogtans vir Vaseline 'n plek waar sy haar in die Septembervakansie probeer afsonder met haar biblioteekboeke (p. 35), 'n terugtrekruimte (vgl. Bain, 2003:197). Weens geldnood moet sy ook gedurende die Kersvakansie in die kinderhuis agterbly.

Vaselinetjie verbind aanvanklik veral negatiewe konnotasies met die omringende omgewing: "Ten spyte van als sien sy daarna uit dat die skool môre moet begin. Sy is trots daarop dat sy selfs in hierdie aaklige plek goed genoeg gedoen het om 'n sertifikaat vir Beste Vordering by die prysuitdeling te kry" (p. 47). Vaselinetjie ken hier 
reeds betekenis toe aan die kinderhuis, al is dit in negatiewe terme, wat die kinderhuis vanuit haar optiek ' $n$ plek begin maak eerder as bloot 'n neutrale ruimte (vgl. Darian Smith et al., 1996:3).

Aangesien Vaseline se identiteitsvorming veelvlakkig is (vgl. Foster 2004:77), is dit uiteraard geen statiese situasie nie - binne die kinderhuis as liminale ruimte verander haar perspektief op sake voortdurend. Dit stuur haar karakterontwikkeling van een liminale fase na die volgende. Die negatiewe perspektief wat aanvanklik oorheers, bereik 'n kulminasiepunt wanneer sy besluit "om op te hou probeer": "Als is verniet. Niemand traak wat jy doen nie, solank jy net nie hulle lewens moeilik maak nie. Van nou af gaan sy soos al die ander kinderhuiskinders maar net deur die aaklige lange dae probeer kom. En as sy opvrek voor dit om is, dan is dit ok maar reg" (p. 68). As sy dan die rook van 'n "entjie" probeer intrek met 'n "harregathouding" ('n riet binne dié konteks) verander iets in haar onherroeplik. Dit word ook gekoppel met perspektief: "Sy gee die entjie vir die ou terug en vir 'n oomblik vang hulle oë mekaar. 'n Vreemde vashoukyk asof hy presies kan sien wat sy vandag gedink en besluit het" (p. 69). In die volgende paragraaf word skielik nie meer van Vaselinetjie gepraat nie, maar van Vaseline (p. 70). Ook Texan van wie hier sprake is, en met wie Vaseline later 'n romantiese verhouding het, is 'n liminale karakter - vandaar dat hulle mekaar se kyk op sake wedersyds kan herken.

Die negatiewe perspektief op die kinderhuis en sy inwoners geld nie alleen vir Vaseline nie, maar ook vir die dorpsbewoners en hulle kinders (soos Nazarene Diergaardt), vir die bibliotekaresses en selfs die skoolhoof. Hierdie negatiewe perspektief is in ooreenstemming met Endsjø (2000:357) se verwysing na ruimtes met 'n "autonomous liminal status within a given worldview" met betrekking tot areas wat hulle buite kultureel-herkenbare raamwerke bevind. Die posisie van die kinderhuiskinders herinner aan Turner (1967:97) se opmerking, dat oorgangsfigure as "particularly polluting" beskou word - vergelyk Vaseline se woorde: "Sy is klaar saam met die ander Peppies deur die wêreld gebrandmerk" (p. 94). Dit kontrasteer sterk met haar naam, wat (soos genoem) met salwing - 'n soort reiniging of goedmaking - verbind word.

Telkens as Vaseline weggaan of wegloop van die kinderhuis af, kom sy in ander liminale ruimtes tereg. Sy loop minstens twee keer weg van die kinderhuis én verlaat een keer om ander redes die kinderhuisgroep in die strandhuis. Die eerste keer vorder Vaselinetjie net tot in die liminale ruimte van 'n boer se landerye en langs 'n spoorlyn. Die tweede keer beland sy in 'n andersoortige 
liminale ruimte wat sy besonder erg vind, naamlik 'n rooiligbuurt in Hillbrow waar sy met die onguurste kante van die lewe te doen kry. Telkens is dus sprake van verdere liminale ruimtes "betwixt and between", gekenmerk deur konflikterende emosies, dubbelsinnighede en verwarring. Ten spyte van 'n nogal ontstemmende busrit daarheen, lyk dit of die strandhuis, gedurende die wonderlike eerste seevakansie wat die kinderhuiskinders onverwags te beurt val, vir Vaseline 'n wending aandui na die goeie. Dan gryp Texan se bendeverlede - en dubieuse etnisiteit - egter kragdadig in op Vaseline se lewe en word haar derde wegloop of "whallap" (hierdie keer egter om die res van die groep te beskerm) vir haar die mees traumatiese liminale fase: "Hulle is vlugtelinge. Van die skollies, van die kinderhuis, van die regering (...) Hulle het niemand nie en hulle ís niemand nie" (p. 136-137). Dit is egter ook die wegloop wat die meeste moontlikhede inhou vir haar verhouding: "a realm of pure possibility whence novel configurations of ideas and relations may arise" (Turner, 1967:97).

Vaseline se perspektief word mettertyd positiewer, veral na haar tweede ontsnapping, haar rampspoedige weglopery saam met Puck na Hillbrow, as sy teenoor die maatskaplike werker, meneer Kedibone, moet erken dat die kinderhuis nie so erg is nie (p. 90). Op p. 95, as Vaseline solidariteit toon met die kinderhuisgroep deur haar hare te laat afskeer uit protes teen Hefner, die hoof van die kinderhuis, beleef sy die ruimte en groep vir die eerste keer anders:

Asof sy deel is van die groep.

Asof sy uiteindelik ook iewers behoort.

Van gister af is dinge skielik heel anders tussen die kinderhuiskinders. Daar is iets in die lug, 'n warm gevoel wat agter aan Vaseline se kraag raak. Asof die Peppies skielik nader aan die meisies staan en hulle almal saam een groep hegte tjoms is. Asof hulle vir mekaar sal opkom en fight as dit moet.

As Vaseline hierna uiteindelik na haar Graad 8-jaar met vakansie terugkeer na Keimoes, het dít intussen vir haar 'n tussenruimte geword. Nie sy of haar pleegouers voel meer gemaklik by mekaar nie (p. 103-106). Dit word ook verbind met perspektief: "Maak nie saak wat Ouma-hulle gesels het nie en hoeveel sy probeer vertel en verduidelik het nie, sy kon die hele tyd iets in hulle gesigte sien. Reg daar, in hulle oë as hulle na haar kyk (...) Oral waar hulle gegaan het, by die winkels, die kerk of om te gaan tee drink by die bure, kon Vaseline daai vreemde kyk by die mense sien" (p. 104). Dit is eers haar oupa se hartaanval wat weer die situasie ten goede verander, 
as sy hom byna verloor (p. 113-114) en sy haar hare weer laat groei.

Deurdat Vaseline saam met haar maats in opstand kom teen gesagsfigure soos Hefner en die skoolhoof, ontstaan 'n gevoel van solidariteit tussen die "kinderhuisrotte" (p. 95) en 'n nuwe identiteitsvorming vind, naas geslag, ook plaas op basis van klas. Dit korreleer met die positiewe attribute wat Turner (1969:99-100) aan die liminale groep toeskryf, naamlik volkome gelykwaardigheid en kameraadskap in "lowliness", wat onderskeidings van klas, ouderdom, familieverwantskap en geslag kan ophef, sodat daar sprake is van communitas in 'n homogene groep (Turner, 1969:96). Die kinderhuis raak nou waarlik vir Vaseline 'n interaksieruimte (Bain, 2003:202), al gaan dit nie minder rof nie (p. 109-110) en behou die ruimte as sodanig steeds 'n liminale essensie. Nog later raak die "Holiday Inn", die lekkerste kamer wat sy boonop met haar goeie maat Killer deel - eers as twee prefekte en dan as hoofmeisie en onderhoofmeisie - gelykwaardig aan haar kamer tuis, in terme van 'n terugtrekruimte (Bain, 2003:197).

Vaseline se godsdiensbelewing word ook as 'n positiewe merker van identiteit in die roman gekonstrueer. 'n Verandering in perspektief wat instrumenteel is in die positiewer liminale fase en wat lei tot groter selfaanvaarding én volwassewording word ingelui wanneer die sielkundige verwys na God as ware Vader (p. 103) en Vaseline 'n tyd daarna vir die eerste keer 'n ernstiger perspektief op God begin kry (p. 125): "Sy weet skielik hierdie dag is 'n belangrike dag in haar lewe, en nie net omdat sy vir die eerste keer die see sien nie (...) Kan oom Issaskar reg wees? dink sy. Dat al weet 'n mens nie wie jou bloedma of bloedpa is nie, kan jy weet God is jou regte-egte Vader? Haar kop voel helder, asof die water en die vreemde, heerlike reuk haar ou gedagtes skoongespoel het" (p. 125). Na haar skokkende ervaring met Texan se halfbroer kom sy tot die gevolgtrekking: "Ek is nie alleen nie. Daar is 'n God en Hy is ook my en Texan se Vader (...) en ek het Hom lief en Hy het my lief. Daar is 'n plan vir my lewe" (p. 150). Haar godsdiensbelewing gee dus aanleiding tot ' $n$ nuwe doelgerigtheid en 'n positiewe instelling: "n Mens kan nie die verlede oordoen nie, maar jy kan altyd besluit wat jy met die toekoms wil maak" (p. 187).

Naas ruimte speel ook naamgewing of die gebrek daaraan, 'n belangrike rol in identiteitsvorming; vergelyk Turner (1967:95): "The transitional-being or 'liminal persona' is defined by a name and by a set of symbols." Aanvanklik boet Vaselinetjie (soos die ander kinders) haar naam in en sy word 'n blote nommer (p. 22). Die 
kinderhuisinwoners kompenseer egter hiervoor deur die wye verskeidenheid byname, soms baie gevat (maar meermale ook wreed eerlik), wat aan kinders gegee word, soos Pizzaface (vir 'n akneegesig), Killer, Puck, Bart (na aanleiding van Bart Simpson p. 98), ensovoorts. Vir die kinderhuiskinders word "Peppies" (p. 27), na aanleiding van Pep Stores se klere wat hulle dra, 'n geusenaam wat hulle saamsnoer.

Namate Vaselinetjie Vaseline word (van p. 69 tot 70) neem sy ook as adolessent in seksuele opsig 'n liminale posisie in. Anders as Timus in Roepman, wie se ontluikende manlikheid en onsekerhede daaroor voorop gestel word, word die seksuele van die karakter Vaselinetjie egter nie sterk uitgelig nie. Olivier (2005) vind dit een van die onoortuigendhede in die teks, maar dit word myns insiens goed gemotiveer deur onder andere Vaseline se konserwatiewe agtergrond, haar naïwiteit en groeiende Christelike geloof. Die seksuele figureer wel dikwels op skabreuse manier by die ander kinderhuiskarakters - niks word ontsien of verswyg nie.

Etnisiteit word sterk op die voorgrond geplaas in die konstruksie van Vaseline se identiteit. Kleur speel saam met taal 'n kardinale rol. Vaselinetjie is naamlik ook in terme van etnisiteit aanvanklik ' $n$ drumpelfiguur in die kinderhuis: sy lyk wit, maar praat soos 'n bruinmens: “'Jy's dan wit soos ek, vir wat praat jy soos 'n hotnot?,' sê Kitcat" (p. 23). Vaseline praat aanvanklik die taal van haar streek en haar ouers (p. 23, 25), maar begin geleidelik steeds meer soos die groep praat en selfs vloek (p. 216). Rassisme is, soos op Keimoes, deel van haar lewe, maar al word die kleur van die karakters in die boek duidelik gemerk, blyk dit spoedig dat die intensiteit van pejoratiewe afslyt in die kinderhuis, net soos die vloekwoorde wat kwistig gebruik word. As Vaseline redelik vroeg in die teks, wanneer sy haar deel voel van die groep, daaroor nadink hoe sy altyd as óf te lig óf te donker gesien word, besluit sy: “... ek gaan nie meer worry of ek nou bruin of baster of wit is met lang, kort of geen hare nie. Hulle almal se hol, ek is net ek!" (p. 95). Haar taalgebruik dien hier by uitstek as merker van groepvorming. As sy uiteindelik saam met Brutus Ithuba (sy bynaam, omdat hy voortdurend krap) matriekafskeid toe gaan, is nie die feit dat hy 'n Zoeloe is vir haar relevant nie, maar die feit dat hy lekker dans. Sy het haar pleegouers verbygesteek in hierdie opsig, as hulle vra: "Is hy dan nie 'n bietjie donker nie?" (p. 243). Ten slotte bevestig sy nogmaals dat die identiteit wat sy mettertyd verwerf het nie afhanklik is van of gegrond is op etnisiteit nie: "Ek gee lankal nie meer om wat die mense dink nie, of ek nou wit of wat is nie" (p. 245). 
Terselfdertyd voel sy ook sterk genoeg in haarself om haar nie aan die gemeenskap se opinies te steur nie.

\section{Ten slotte}

Die krag van Vaselinetjie het te doen met die manier waarop die tema, die oorgangsfase van kind na volwassene, aan die hand van verskillende ruimtes, grensoorskrydings en perspektiewe gekonstrueer word. Soos blyk uit die voorafgaande bespreking, verander die kinderhuis in talle opsigte vanuit Vaseline se perspektief van 'n liminale ruimte ("set apart") met inherent liminale eienskappe, na 'n plek, 'n tuiste (hoe gebrekkig ook al), 'n landskap van behoort te midde van ander met byname en onsekerhede soos sy. In die proses beleef die hoofkarakter eerstens skeidingsrites ("rites of separation") ten opsigte van haar aangenome ouers, liminale of oorgangsrites met betrekking tot haar aanvanklike skooljare in die kinderhuis en met verloop van tyd insluitingsrites ("rites of incorporation") ten opsigte van die groep Peppies in die kinderhuis. Die karakter se ontwikkeling vanaf ' $n$ preliminale, deur ' $n$ liminale en tot by 'n postliminale fase word op ' $n$ oortuigende manier uitgebeeld. $\mathrm{Na}$ haar terugkeer na haar ouerhuis wanneer haar skoolopleiding voltooi is, ervaar Vaseline ook dáár volkome aanvaarding. Sy slaag haar matriek, bevestig dat sy volkome onverskillig staan teenoor huidskleur - en die moontlikheid van 'n versoening met haar geliefde Texan word selfs in die vooruitsig gestel.

Hierdie slot is volgens die outeur self nie realisties binne die konteks van wat sy ten opsigte van kinderhuiskinders ervaar het nie en kan dus in ' $n$ sekere sin as 'n manipulasie beskou word. Volgens Von Meck (in 'n gesprek tydens Woordfees 2005) wou sy die roman doelbewus hoopgewend laat eindig, juis omdat dit in die ware lewe dikwels nie die geval is nie, soos die lotgevalle van karakters soos Marietjie en Puck ook uitwys. Binne die roman lyk dit wel by die eerste lees bevredigend dat die meeste verhale bevredigend sluit, maar die ietwat onwaarskynlike geluksaligheid teen die einde bring tog andersyds mee dat die gegewe in 'n mate tematies vervlak. Sowel Vaselinetjie se positiewe perspektief op die lewe as die karakterontwikkeling wat sy ondergaan in die loop van "rites of passage" (Van Gennep, 1977:11), maak van Vaselinetjie dus uiteindelik 'n hoopvolle boek, wat ingaan teen Killer se uitspraak: "kinderhuiskinders leer om baie te verdra, maar hoop is die ergste. En die wreedste" (p. 42). 
Laasgenoemde aanhaling wys egter andersyds dat die volgende uitspraak van Endsjø (2000:357) steeds geld ten opsigte van die kinderhuis as ruimte:

As culturally recognised places are carved out of an originally undefined territory, huge areas will also remain outside of these culturally recognised frames (...) the periphery seems to possess something of the same phenomenological essence as the liminal phase of the transitional rites, a certain liminal essence that belongs to these landscapes, quite independent of transitional rites.

As ruimte met 'n sekere liminale essensie (wat ek onderskei van die veranderende en ontwikkelende perspektiewe daarop, deur die onderskeie karakters in die algemeen en Vaseline meer in die besonder) kan die kinderhuis binne die sosio-politieke konteks van die nuwe Suid-Afrika, waar die kinderhuiskinders baie ironies "kinders van Madiba" genoem word, moontlik as eksemplaries gelees word van 'n sosiale bestel - 'n bestel waarin kleurverskille verwaarloosbaar raak namate solidariteit en wedersydse lojaliteit toeneem; 'n liminale fase tussen ou beperkings en nuwe moontlikhede, in "a realm of pure possibility" (Turner, 1967:97).

Vanuit Vaseline se perspektief is die kinderhuis beslis ' $n$ transformerende ruimte. Al is daar sprake van "ambiguity and discontinuity" gaan dit ook om "... the transformative potential of space", wat Vaseline as jong vrou bemagtig "to challenge and negotiate an adult world of rules and regulations" (Bain, 2003:202203). Uit die roman blyk ook dat liminaliteit in bepaalde opsigte steeds 'n deurlopende proses in die lewe bly en nooit op alle vlakke as afgehandel beskou kan word nie. Die ontwikkeling van identiteit is nie slegs veelvlakkig nie, maar ook verskuiwend - karakters soos Vaseline bevind hulle (soos mense in die werklikheid) in mindere of meerdere mate deurlopend in preliminale, liminale en postliminale fases, en ook meermale in ruimtes met 'n sekere liminale essensie.

\section{Geraadpleegde bronne}

ANON. 2005. Via Afrika- en M-Net se literêre pryse bekroon beste skryftalent van 2004. Die Burger: 10, 20 Jun.

ASHCROFT, B., GRIFFITHS, G. \& TIFFIN, H. 1989. The empire writes back; theory and practice in post-colonial literatures. London: Routledge.

BAIN, ALISON L. 2003. White Western teenage girls and urban space: challenging Hollywood's representations. Gender, Place and Culture, 10(3):197-213. 
DARIAN-SMITH, K., GUNNER, L., \& NUTTAL, S., eds. 1996. Text, theory, space: land, literature and history in South Africa and Australia. London: Routledge.

ENDSJØ, DAG ØISTEIN. 2000. To lock up Eleusis: a question of liminal space. NUMEN, 47:351-386.

FOSTER, P.H. 2004. Marginale en liminale karakters in die werk van Lettie Viljoen/Ingrid Winterbach: sosiale kommentaar en die ondermyning van grense. Stellenbosch: Universiteit van Stellenbosch. (Ongepubliseerde M.A.-verhandeling.)

LARSON, REED. 1995. Secrets in the bedroom: adolescents' private use of media. Journal of Youth and Adolescence, 24:535-549.

OLIVIER, FANIE. 2005. Lesers oud én jonk verdien meer respek. Beeld: 24, 13 Jan.

SEBBA, RACHEL \& CHURCHMAN, ARZA. 1983. Territories and territoriality in the home. Environment and Behavior, 15:191-210.

SIBLEY, DAVID. 1995. Geographies of exclusion: society and difference in the West. London: Routledge.

STEELE, JEANNE \& BROWN, JANE. 1995. Adolescent room culture: studying media in the context of everyday life. Journal of Youth and Adolescence, 24:551-576.

TURNER, VICTOR W. 1967. The forest of symbols: aspects of Ndembu ritual. Ithaca/London: Cornell University Press.

TURNER, VICTOR W. 1969. The ritual process: structure and anti-structure. London: Routledge \& Kegan Paul.

TURNER, VICTOR W. 1982. From ritual to theatre: the human seriousness of play. New York: Performing Arts Journal Publications.

TURNER, VICTOR W. \& TURNER, EDITH. 1978. Image and pilgrimage in Christian cultural anthropological perspectives. New York: Columbia University Press.

VAN GENNEP, ARNOLD. 1977 [1960]. The rites of passage. London: Routledge \& Kegan Paul.

VAN TONDER, JAN. 2004. Roepman. Kaapstad: Human \& Rousseau.

VILJOEN, LOUISE. 2005. Roepman is 'n aangename verrassing. Litnet, 13 Jan.

VON MECK, ANOESCHKA. 2004. Vaselinetjie. Kaapstad: Tafelberg.

VON MECK, ANOESCHKA. 2005. Deur die oog van 'n kind: gesprek met Anoeschka von Meck en Jan van Tonder tydens Woordfees 2005. Gesprekleier Dorothea van Zyl. 12 Maart.

WEKKER, GLORIA \& LUTZ, HELMA. 2001. Een hoogvlakte met koude winden: de geschiedenis van gender- en etniciteitsdenken in Nederland. (In Botman, Maayke, Jouwe, Nancy en Wekker, Gloria, reds. Caleidoschopische visies: de zwarte, migranten- en vluchtelingenvrouwenbeweging in Nederland. Amsterdam: Koninklijke Instituut van de Tropen. p. 25-49.)

WILLIAMS, RHONDA M. 1998 [1997]. Livina at the crossroads: explorations in race, nationality, sexuality, and gender. (In Lubiano, Wahneema, ed. The house that race built. New York: Vintage Books. p. 136-156.) 


\section{Kernbegrippe:}

konstruksie van identiteit

liminaliteit

ruimte, plek en landskap

Von Meck, Anoeschka

\section{Key concepts:}

construction of identity

liminality

space, place and landscape

Von Meck, Anoeschka 